\title{
Gene Therapy: An Overview
}

Shivani Kachroo ${ }^{1}$ and Sivakumar JT Gowder ${ }^{2^{*}}$

${ }^{1}$ Delhi Technological University, New Delhi, India

${ }^{2}$ Qassim University, College of Applied Medical Sciences, Buraidah, Kingdom of Saudi Arabia

${ }^{*}$ Corresponding author: Sivakumar Gowder, College of Applied Medical Sciences, Qassim University, Buraidah, Kingdom of Saudi Arabia, Tel: +966566873969; Fax: +96663802268; E-mail: sivakumargowder@yahoo.com

Rec date: Feb 22, 2016; Acc date: Feb 23, 2016; Pub date: Feb 25, 2016

Copyright: ( 2016 Kachroo S, et al. This is an open-access article distributed under the terms of the Creative Commons Attribution License, which permits unrestricted use, distribution, and reproduction in any medium, provided the original author and source are credited.

\section{Editorial}

The idea of gene therapy is unique; it works by the addition of a healthy gene in place of a defective or faulty candidate genes so that the changes in the gene function in the patient's body are retained and restored. It represents a means to treat a disease in a more innovative way by use of genetic materials leading to expression of proteins in the cells which interfere with the synthesis of proteins to treat diseases. Different vector systems perform gene transfer with certain advantages and disadvantages. Several technical issues must be overcome before fruitful and complete cure are possible, and technologies must continually be improved. Like all medical therapies, gene therapy will ameliorate some, but not all type of diseases. Various approaches are being examined in clinical trials for gene therapy [1]. Targeting genetic lesions of tumor cells, immunomodulation by gene therapy, genetically modified tumor vaccines in gene therapy, co-stimulatory molecules, DNA vaccines, 'Suicide' gene therapy, etc. are the important ones. Before gene therapy can become the strategy of choice for a wide variety of clinical settings, there will be an improvement in the efficiency of gene transfer into target cells. The problem of efficient gene transfer will require not only further research to improve effective delivery systems and vector construction but also a parallel effort to understand the biology of the target cells. A better understanding of disease etiology, pathogenesis especially in inherited, mutagenic or acquired diseases will have a positive impact on the treatment strategies.

The successful implication of gene therapy in the treatment of monogenic disorders-SCID, diabetes mellitus, hemophilia, cancer and the other life-threatening diseases has been already reported [2-5]. Recent reports also reveal therapy to restore lost tumor suppressor gene function, application of RNA therapeutics in the treatment of oral diseases and DNA repair targeted therapy in the treatment of cancer [6-8]. The ongoing developments in cell and molecular biology research, combined with the unfolding of the human genome and advances in bio-informatics, has made the concept of specific gene therapies more viable and promising. The stability, fidelity, and amplification of the delivered therapeutics can be guaranteed by more information on the system. Gene therapy involves the regenerative potential of the potent stem cells and transplantation techniques as the biological weapon of immunity, which is utilized for the successful removal of the cells. By taking advantage of these inbuilt biological specialized systems, gene therapy can cater to the still unidentified medical needs of both rare and common severe diseases, which will benefit both patients and the society. Significant challenges must still be addressed before this promise can be realized. The efficiency and performance of the gene-transfer vectors could be improved by further modifying their designs and features, which could include combining the biological aspects of different viruses with man-made /artificial ones [9].

The tremendous advances in genetics, molecular biology, bioinformatics, etc. have paved new ways for the exploration of gene therapy. Advanced techniques are needed to speed up the progress of gene therapy. No doubt, in the future, gene therapy will play an incredible role in medicine.

\section{References}

1. Amer MH (2014) Gene therapy for cancer: present status and future perspective. Mol Cell Ther 2: 27 .

2. Cavazzana-Calvo M, Hacein-Bey S, de Saint Basile G, Gross F, Yvon E, et al. (2000) Gene therapy of human severe combined immunodeficiency (SCID)-X1 disease. Science 288: 669-672.

3. Jun HS,Yo JW (2005) Approaches for the cure of type 1 diabetes by cellular and gene therapy. Curr Gene Ther 5: 249-262.

4. Kay MA, Manno CS, Ragni MV, Larson PJ, Couto LB, et al. (2000) Evidence for gene transfer and expression of factor IX in haemophilia $\mathrm{B}$ patients treated with an AAV vector. Nat Genet 24: 257-261.

5. Khuri FR, Nemunaitis J, Ganly I, Arseneau J, Tannock IF, et al. (2000) a controlled trial of intratumoral ONYX-015, a selectively-replicating adenovirus, in combination with cisplatin and 5-fluorouracil in patients with recurrent head and neck cancer. Nat Med 6: 879-885

6. Elangovan S, Kormann MS, Khorsand B, Salem AK (2016) the oral and craniofacial relevance of chemically modified RNA therapeutics. Discov Med 21: 35-39.

7. Birkeland AC, Ludwig ML, Spector ME, Brenner JC (2016) The potential for tumor suppressor gene therapy in head and neck cancer. Discov Med 21: 41-47.

8. Gavande NS, VanderVere-Carozza PS, Hinshaw HD, Jalal SI, Sears CR, et al. (2016) DNA repair targeted therapy: The past or future of cancer treatment? Pharmacol Ther S0163- 7258(16)00032-2.

9. Naldini L (2015) Gene therapy returns to centre stage. Nature 526: 351-360. 